\title{
İlkokullarda Okul Sosyal Hizmetinin Gerekliliğinin Öğretmen Gözüyle Değerlendirilmesi
}

\author{
Esma Aynur GÖKGÖZ * \\ Bedrettin KESGIN **
}

\section{Özet}

İlkokul eğitiminde, öğrenciler ders saatleri içerisinde ya da dışında dersler, okul ortamı, arkadaşlar, aile veya başka faktörlerle ilgili birçok problemle karş1laşmaktadırlar. Rehber öğretmenler ve sınıf öğretmenleri bu problemlerin çözümünde yetersiz kalabilmektedirler. İlkokullarda eğitim kalitesinin artırılmasında, bunun yanında öğrencilerin okuldan, aileden ve sosyal çevreden kaynaklanan sorunlarının çözümünde önemli bir görevi yerine getireceği düşünülen okul sosyal hizmeti kavramı son zamanlarda sıkça tartışılmaktadır.

Bu çalışmanın amacı; ilkokul eğitimindeki sorunları yakından gözlemleyen öğretmenlerin bakış açısıyla okul sosyal hizmetinin gerekli olup olmadığını ortaya çıkarmaktır.

Anahtar kelimeler : Okul sosyal hizmeti, sosyal hizmet, eğitim.

\section{An Evaluation Of School Social Service Necessity In Primary Schools With Teacher Perspective}

\begin{abstract}
In primary school education, within or outside of school hours, students are facing a lot of problems related with classes, school environment, friends, family or other factors. Student advisor teachers and class teachers may be unsufficient

\footnotetext{
* Yalova Üniv. SBE, Sosyal Hizmet Ana Bilim Dalı Yüksek Lisans Programı, esmaaynur2009@hotmail.com.

** Doç.Dr., Yalova Üniv. İİBF Sosyal Hizmet, bedrettink@gmail.com.
} 
in solving these problems. Recently the concept of school social service is being discussed frequently which is thought to fulfill an important mission via improving the quality of education as well as solving the problems of students arising from school, family and social environment in primary schools.

The aim of this study; exploring that school social work is needed or not in the perspective of teachers who closely observe problems in primary school education.

Key words: School social service, social service, education.

\section{Giriş}

Eğitim, bireyin doğumuyla başlayıp ölümüne kadar devam eden, istendik davranış değişikliği oluşturma ve beceri kazandırma sürecidir. Bireyin davranışlarında olumlu değişimlerin olmasını sağlayan faaliyetler bütünü, bireyin yaşamını kaliteli bir şekilde devam ettirmesine katkı sağlayan bir faktördür. Birey içine doğduğu çevre ile etkileşime geçerek içinde yaşayacağı toplum ve çağın özelliklerini eğitimle edinmektedir. Dolayısıyla eğitim bireyin okul hayatıyla değil içine doğduğu çevreyle başlayan bir süreç olarak görülmektedir.

Bireyin içine doğduğu çevresi, kendisiyle aynı kan bağı ile birbirine bağlı bireylerden oluşabileceği gibi, bireyle hiçbir kan bağı olmadığı hâlde onunla aynı çatı altında yaşayan, onun sosyal, ekonomik ve psikolojik ihtiyaçlarını karşılayan bireylerden de oluşabilmektedir. Bireyin içinde yaşadığı çevre onun ailesini oluşturmaktadır.

Bebeklik ve okul öncesi dönemde ailenin yanında geçirilen ilk altı y1llık süre azımsanmayacak bir süre olarak görülmektedir. Bu süreçler çocuğun kişiliğinin oluşumunda etkili olan süre olarak kabul edilmektedir. Yani eğitim, daha çocuk okula gelmeden önce başlayan ve okulda devam eden bir süreç olmaktadır. Aile ve okul bir bireyin yaşamında etkili olan iki temel toplumsal kurum olarak kabul edilmektedir. 
Çalışma ile Yalova ilinde faaliyet gösteren bir ilkokulun 32 öğretmeni ile kişisel görüşme yapılmıştır. Kişisel görüşmede ilkokul eğitiminde karşılaşılan problemler tespit edilmeye çalışılmış ve bu bağlamda problemlerin çözümü için okul sosyal hizmeti biriminin okullarda gerekliliği ortaya çıkmıştır. Öğretmenlerle yapılan mülakat sonuçları değerlendirildiğinde, öğrencilerin aileden, sosyal çevreden ve okuldan kaynaklanan birçok problem tespit edilmiş ve okul sosyal hizmeti biriminin söz konusu problemlerin çözümüne katkı sağlayacağı sonucuna ulaşılmıştır.

\section{Eğitim ve Sosyal Hizmet İlişkisi}

Eğitim, "insanın doğumdan ölümüne değin toplumsal ilişkiler içinde yaşadığ 1 kesintisiz değişim süreci, kültürlenme ve toplumsallaşma süreci (Tomanbay, 1999: 76)" olarak ifade edilmektedir. Yine eğitim, bireye toplumda ona her yönden fayda sağlayacak istendik davranışlar edindirme sürecidir. Eğitim, "yetişkin nesiller tarafından, başta çocuk ve gençler olmak üzere, sosyal hayata henüz hazır olmayanlar için bilgi, hüner, beceri, güzel ahlâk, terbiye edinmeye yönelik uygulanan faaliyetlerin bütünüdür" (Seyyar ve Genç, 2010: 196).

Eğitim sürecinde bireye bedenî, zihnî, ruhî ve sosyal yönden birtakım beceriler kazandıranlar bireyin ailesi, çevresinde yer alan diğer kişiler ve okul çağında da öğretmenleridir. Hem aile hem öğretmen bireyin eğitiminden sorumlu olmaktadırlar.

Eğitim, öğretimi de içine alan bir kavramdır. Öğretim bireye bilgi kazandırma kısmını kapsarken, eğitim de bireye öğretilen bu bilgilerle onun davranışlarını, tutumlarını olumlu bir hâle getirmeyi kapsamaktadır. Yani eğitimsiz öğretimin, öğretimden yoksun bir eğitimin olması mümkün olmadığ ifade edilmektedir. Dolayısıyla eğitim dediğimizde aklımıza hem eğitim hem öğretim gelmektedir.

Eğitim sürecinde birey, aile, arkadaş, öğretmen, sokaktaki insanlar, akrabalar, büyükler, komşular, kitle iletişim araçları ile karşılaşmaktadır. Bunların özellikleri bireyin eğitiminde etkili olmaktadır. 
Sosyal hizmetin ise eğitim yanında başka birçok yönü vardır. Sosyal hizmet sosyal politikanın bir çalışma alanı olarak görülmektedir. Üst başlık olarak sosyal politika, devletin ideolojisine ve toplumların gelişmişlik düzeylerine göre değişen bir devlet politikası olarak kabul edilmektedir. Piyasayı düzenleyen ve geliri yeniden dağıtma özellikleri ile refah devletleri uygulama alanı bulmuştur. (Koray, 2005 ve Göze, 1995)

Sosyal politikanın amacı huzur ile refahın aynı anda gerçekleştirilmesini hedeflemektir (Bozkır Serdar, 2011: 2-3).

Sosyal politika, sosyal güvenliklerin ve sosyal hizmetlerin bir bütünlük içinde sağlanması, çalışma ve sosyal hayata yönelik düzenleyici ve iyileştirici politikalar, ekonomik açıdan bazı sosyal kesimlerde oluşan maddi olumsuzlukları ve sosyal adaletsizliği gidermeye yönelik faaliyetler bütünüdür (Seyyar ve Genç, 2010: 728-729).

Ancak sosyal politikanın çalışma alanlarından biri olarak görülmekte olan sosyal hizmet gerek resmi kurumlar aracılığıyla gerekse sivil ve enformel kanallar aracılığıyla günlük yaşantı içerisinde gelenek ve göreneklerle, gönüllü kuruluşlar aracılığıyla yapılmaktadır. Sosyal hizmet sosyal güvenliğin alt dalıdır ve toplumsal refahı ve uyumu hedefler (Tomanbay, 2001: 27).

Sosyal hizmet, bir bireyin maddi ve manevi yoksunluklarının giderilmesi için yapılan çalışmaların bütünü olarak kabul edilmektedir. Sosyal hizmet, çok disiplinli yaklaşımla insanı bir bütün olarak değerlendirerek onun her bir ihtiyacıyla ilgili olan mesleki ve bilimsel alanlarla işbirliği içinde çalışmayı hedeflemektedir. Sosyal hizmet, bireylerin kendi iradeleriyle ya da kendi iradelerindeki sebeplerden kaynaklanan maddi ve manevi yoksunlarıyla baş edebilmelerini sağlamaya yardımcı olmayı hedeflemektedir.

Sosyal hizmetler, ayni olarak sağlanan ve bedelsiz veya normal piyasa fiyatının altından daha düşük fiyattan satın alınan hizmetleri ya da kullandırılan barınma, sağlık, eğitim gibi hizmetleri karşılar (Arın, 1997: 331). Sosyal Hizmetler Kanunu'nda belirtildiği gibi "sosyal hizmetler"; kişi ve ailelerin kendi bünye ve çevre şartlarından doğan veya kontrolleri dışında oluşan maddi, manevi ve sosyal yoksunluklarının giderilmesine ve 
ihtiyaçlarının karşılanmasına, sosyal sorunlarının önlenmesine ve çözümlenmesine yardımcı olunmasını ve hayat standartlarının iyileştirilmesi ve yükseltilmesini amaçlayan sistemli ve programlı hizmetler bütününü ifade eder.

Sosyal hizmet, fertlerin birbirleriyle ve sosyal çevresi ile uyum içinde yaşamasını kolaylaştırırken insana, şeref ve haysiyetine uygun yaraşır eğitim, danışmanlık, bakım, tıbbî ve psiko-sosyal rehabilitasyon alanlarında devlet, özel ya da gönüllü kuruluşlar tarafından sistemli bir şekilde verilmekte olan programlar olarak belirtilmektedir. İnsanlara psiko-sosyal işlevselliği kazandırmaktadır. Kötü sosyal şartları ortadan kaldırmak ve sosyal sorunlu kişi ve ailelere maddi ve manevi (sosyal) destek sağlamaktadır. (Seyyar ve Genç, 2010: 684)

Sosyal hizmetin hedefleri, amaçları ve kapsamı daha geniş olmaktadır. Sosyal hizmetin, insanın gelişmesine katkı sağlamak, bireyin toplum içinde onurlu bir şekilde var olmasına destek olmak, toplumun sorunlarını çözme ve toplumu koruma yanında, sosyal refahın gelişmesi ve gelirin adil bir şekilde dağılmasına yardımcı olma gibi çoklu boyutları vardır (C1lga, 2002).

Bireyin karşılaştığı maddi yoksunluğunu gidermek amaciyla sosyal yardımlar yapılmaktadır. Sosyal yardım, sosyal hizmetin içinde yer almaktadır. Sosyal yardımlar ayni ve nakdi olarak ikiye ayrılmaktadır. "Ayni sosyal yardımlar, en eski sosyal yardım uygulamasıdır. Ayni sosyal yardımlar, muhtaç bireyin mal ve malzeme cinsiyle aldığı yardımları ifade eder (Kesgin, 2013: 48). Koşar'a ve Çengelci'ye göre sosyal yardım, sosyal hizmetin uygulama alanlarından sadece biridir (Koşar, 2000 ve Çengelci, 1996).

Sosyal hizmet çok boyutlu, uzak hedefleri de gerçekleştirmeyi amaç edinen ve sorunun temeline inip, onu kaynağında çözmeye yönelen bir gerçekliğe sahiptir. Sosyal yardımlarda yardım daha çok nakdi olarak yerine getirilirken, sosyal hizmetlerde yardım, "hizmet" şeklinde yerine getirilmektedir (Gerek ve Oral, 2004: 43).

Sosyal hizmetin birtakım esasları bulunmaktadır. Sosyal hizmetler, bireyler arasında din, dil, ırk, cinsiyet, mezhep, sınıf, bölge ve siyasi 
düşünce farklılığı gözetilmeden; hiçbir vatandaşa, aileye, ferde, vatandaşa ayrıcalık tanınmadan; devletin denetim ve gözetiminde, insan haysiyet ve şerefine saygı gösterilerek, kamu kurum ve kuruluşları arasında işbirliği sağlanarak yapılmaktadır. Sosyal hizmet faaliyet ve programları coğrafik ve fonksiyonel görev dağılımı dengeli bir şekilde dağıtılmaktadır. Çocuklara yönelik hizmet çalışmalarında öncelik çocuğun ailesi ya da aile yakını kapsamında olmaktadır. Sosyal hizmet uzmanları tarafından sosyal hizmet ihtiyacına göre uygun görülen kişi ya da gruba yönelik verilmekte olan spesifik sosyal hizmet uygulamaları kapsamında sosyal hizmet türlerinin ortaya çıktığı görülmektedir. Türleri incelendiğinde, tıbbi sosyal hizmetler, psikolojik sosyal hizmetler, orduda sosyal hizmetler, mesleki sosyal hizmetler, manevi sosyal hizmetler, işletmede sosyal hizmetler, çok kültürlü sosyal hizmetler ve okulda sosyal hizmetler bulunmakta, bunun gibi birçok sosyal hizmet bulunmaktadır.

\section{Okulda Sosyal Hizmet ve İlkokulda Okul Sosyal Hizmetinin Gerekliliği}

Okul, "toplumda çocuklara ve genç nesillere öğretilecek şeylerin, düzenli ve etkili bir şekilde yetkili ve ehil kimselerce verilmesi maksadıyla ortaya çıkan eğitim ve öğretim kurumu (Seyyar ve Genç, 2010: 529)” olarak ifade edilmektedir.

Dupper (2013: 21)' a göre okul, “sınıf içinde öğrencilerin eğitildiği ve sosyalleştiği üretim alt sisteminin ana parçası" olarak görülebilir. Okul, bireylerin her yönden gelişiminde, yetiştirilmesinde, nitelikli ve sağlık1 kişilik sahibi bir insan olarak toplumda yer almalarının sağlanmasında etkili eğitim kurumları olmaktadır. Okullar çocukların ailelerinden sonra kendilerini içinde buldukları ilk toplumsal kurum olmaktadırlar.

Bir yandan okul, eğitim aracılığıyla insanı kendisi için yararlı ve yeterli kılmaya çalışırken bir yandan da insanı içinde yaşadığı topluma ve tüm insanlığa yararlı, toplumsal bilinci gelişmiş bir insan olması için eğitmeyi amaçlamaktadır (Yavuzer, 2001: 87). 
Okul sosyal hizmeti, öğrencilerin okul eğitimi çerçevesinde psiko-sosyal sorunlarını çözmeye dönük sosyal hizmet uygulamaları şeklinde ifade edilmektedir. Okul sosyal hizmeti uygulamaları kapsamında, danışmanlık ve rehberlik, okul dışı boş zamanların faydalı bir şekilde değerlendirilmesine yönelik boş zaman faaliyetleri, gençlik sorunlarının çözümüne yönelik manevî, meslekî ve sosyal destek hizmetleri verilmektedir (Seyyar ve Genç, 2010: 529-530).

Devlet ilkokulları Milli Eğitim Bakanlığına bağlı olarak eğitim ve öğretim faaliyetlerini yürütmektedir. Okullar toplumda kendini düzgün bir şekilde ifade edebilen, araştırıcı ruhlu, plânlı programlı çalışan, fikirler üretebilen, davranışlarıyla uyumlu bireyler yetiştirmeyi hedeflemektedir.

$\mathrm{Bu}$ hedeflerin gerçekleştirilmesi sürecinde arkadaşlarına fiziki zarar veren, arkadaşlarıyla oyun oynamakta zorlanan, dışlanan, eğitim ve öğretim araç gereçlerini düzenli getirmemekte israr eden, çok boş zaman geçiren, aile problemleri yaşayan bu sorunları konuşmak istemeyen, içe dönük, içteki problemlerini dışa saldırganlık olarak yansıtan, kaynaştırma eğitimi raporu olan, hiperaktivite ve hiperaktiviteye bağlı ilaç kullanan öğrencilerle ve benzeri durumlarla da karşılaşılabilmektedir. Bunlar öncelikli olarak eğitim sorunu olarak görülse de bu sorunların gerek oluşma aşamasında gerekse sonuçları itibariyle ailevi ve toplumsal boyutları da vardır. Bu noktada öğretmenler kimi zamanlarda yeterli olamamakta ve öğrencileri okul rehberlik servisine yönlendirmektedir. Ancak bazı durumlarda özellikle aileye ulaşılamayan sebeplerden dolayı problemlerin çözülmesi mümkün olmamaktadır. Ya da öğrenci velileri bazı durumlarda çocuklarına nasıl yaklaşacaklarını bilmedikleri için, ayrıca çocuklarının gelişim özellikleri hakkında yeterli bilgiye sahip olmadıklarından dolayı okulda öğretmenle konuşulan diyaloglar olumlu gibi gözükse de bu durum her zaman olumlu sonuçlar oluşturamamaktadır. Bu sorunların çözüme kavuşturulması için devletin yeni sosyal politikalar üretmesi gerekmektedir. Her zaman ifade edilmekte olan öğretmen-veli-öğrenci işbirliğinin daha da önemsenerek ve özümsenerek devam ettirilmesi gerekmektedir. $\mathrm{Bu}$ işbirliğinin göstergelerinden belki de en önemlisi Milli Eğitim ve Aile ve Sosyal bakanlıkları politikalarının işbirliğinde görülebilecektir. 
Milli Eğitim Bakanlığı ile Aile ve Sosyal Politikalar Bakanlığı okulda sosyal hizmet sistemini kurma amaçlı bir proje oluşturmaya hazırlanmaktadırlar. Bu proje kapsamında okulda şiddet öyküsü olan ve şiddete eğilimli çocuklar belirlenerek onlara psiko-sosyal destek verilmesi amaçlanmaktadır. Bu proje kapsamında her okulda bir sosyal hizmet biriminin kurulması ve buralarda, sosyal çalışmacı, psikolog ve sosyologların görevlendirilmesi planlanmaktadır. Bu birimlerin rehberlik öğretmenleri ve okul aile birlikleriyle koordineli bir şekilde çalışacakları belirtilmektedir. Hizmet birimlerinde sigara, alkol, madde bağımlılığı gibi zararlı alışkanlıklar edinmiş, uyum ve iletişim sorunu yaşayan çocuk ve gençler için çözüm modellerinin belirleneceği, koruyucu-önleyici ve rehabilite edici değerlendirmeler yapılarak, öğrenciye destek olunacağı, bu birimlerin, okullarda öğrencilerin öğretmenleri ile ya da ailesi ile sorun yaşayan öğrenciler için de bir arabulucu görevi üstleneceği belirtilmektedir (Kahvecioğlu, 2014).

Okul sosyal hizmetine tüm öğrencilerin ve velilerin ihtiyacı olduğunun da unutulmaması gerekmektedir. Davranış bozukluğu çeken öğrenci ailelerinin, bu gibi sorunlardan diğer öğrencilerin başarı ve davranışlarının olumsuz etkilenmemesi için ailenin bu eğitim sürecinin içinde olması gerekmektedir. "Aile eğitimi”" ile ailelerin üzerlerine düşen görevleri yerine getirmeleri gerekmektedir. Okul içindeki tüm öğrencilere yönelik olarak, onların başarısının arttırılmasında, ailelere neler yapabilecekleri konularında destek hizmetlerinin verilmesi bu açından önem arz eder.

Okul sosyal hizmeti uzmanları her bir okulun çevresine göre farklı gereksinimleri karşılamak için çalışmalar yapmaktadır. Çünkü sosyal hizmet uzmanları ekolojik bakış açısını kullanmaktadırlar. Sosyal hizmet uzmanları çocukların eğitim ihtiyaçlarının anlaşılması, risk altındaki öğrencilerle ailelerin desteklenmeleri, ailelerin endişelerinin okul çalışanları ile paylaşabilmelerinin güçlendirilmesi, öğrencilerin yaşam koşulları, yaşadıkları mahallelerin koşullarının incelenmesi, farklı kurumlara yönlendirmeler yapmayı, farklı kurumlara yönlendirilmiş olan öğrencilerin takip edilmesi gibi görevler üstlenmektedir. Burada Dupper' in analizine başvurularak soruna yaklaşılacaktır.

YIL: 5 SAYI: 9 
Okul sosyal hizmet uzmanları, sınıf aktiviteleri yürütebilmekte, okul-temelli önleme programları tasarlayabilmekte, öğrencilere bireysel ya da grup danışmanlığı hizmetleri sunabilmektedirler. Ayrıca okul sosyal hizmet uzmanları okul ortamındaki geniş kapsamlı problemleri çözmek için birden çok rolü üstlenmektedirler. Dupper'e göre sosyal hizmet uzmanları ekolojik bakış açısı ile insanların baş etme kapasitelerini ve gelişme potansiyellerini güçlendirmek ve çevrenin birey üzerinde oluşan etkisini olumlu yönde geliştirmek gibi sosyal hizmet müdahalelerinde iki yönlü odaklanmayı benimsemektedirler. Okul ve çevresi arasında ilişkinin anlaşılmasında faydalı olan kavram sınırlar kavramı olarak kabul edilmektedir. Bazı öğrenciler okul davranışını yönlendiren kurallar ile evde, mahallede davranışını yönlendiren kuralları karşılaştırmasının sonucunda çatışma içinde olmaktadırlar. Bu çatışmanın çözülebilmesi için evde var olan davranış kuralları ile okulda var olanlar arasında uyumun olması öğrencinin her iki ortama uyumunu kolaylaştırmaktadır. Bu nedenle okul sosyal hizmet uzmanların kurallar ve beklentileri anlamada zorluk çeken öğrenci ve ebeveynlerine ulaşarak yardımcı olmaları gerekmektedir (Dupper, 2013: 20).

Okul ortamındaki kurallara alışabilmesi için ailenin çocuğuna okul kültürü hakkında önceden bilgiler vermesi ve bizzat kendilerinin çocuk yetiştirirken özellikle davranış kuralları konusunda tutarlı davranarak çocuklarına örnek olmaya çalışmaları önem arz etmektedir.

Öğrencilerin sınıfta gürültülü ya da düzensiz olmaları, öğretmenin yönergelerini uymamaları, sıralarını terk etmeleri, bağırmaları, kopya çekmeleri gibi davranışları sınıf içi davranış problemleri olarak belirtilmektedir. Sosyal hizmet uzmanları ve eğitimcilerin bu davranışlarla beraber zorbalık etme davranışına da ilgi göstermeleri gerekmektedir. Çünkü zorbalık etmek; başka bir öğrenciye, bir öğrenci ya da bir öğrenci grubu tarafından provoke edilmeksizin fiziksel ya da psikolojik baskıda bulunma ve zamanla bunu standart bir yapıya kavuşturma olarak ifade edilmektedir. Okul sosyal hizmet uzmanları ilk olarak saldırılara maruz kalanları korumak için her türlü çabayı göstermeli ve diğer okul çalışanlarından da bu yönde ellerinden gelen çabayı göstermelerini istemeleri gerekmektedir (Dupper, 
2013: 33-35). Öyleyse okullarda arkadaşından şiddet, zorbalık gören çocuklara yönelik de bir okul sosyal hizmet çalışması gerekmektedir.

Öğrencilerde şiddet içerikli çizimler ya da yazılar, akranlarını şiddet gösterme ile tehdit etme, saldırganlık geçmişi, yakın zamanlarda yaşanan ilişki kopmaları, kendilerini diğer öğrencilerden soyutlama, dalga geçme ya da dalga geçildiğini düşünme, hayvanlara eziyet etme, madde kullanımı, aile içi sorunlar, okula olan düşük ilgi, sosyal olarak içine kapanma, rastgele silah kullanımı ya da silahın kolaylıkla elde edilmesi, diğer öğrencilerden farklı olarak tanımlanmak gibi durumlar şiddet sergileme potansiyeli olan öğrencileri tespit etmek için adımlar olarak belirtilmektedir (Dupper, 2013: 37-40).

Özellikle bahse konu olan desteklerin ilkokul çağlarında daha büyük gereksinim oluşturduğuna şüphe yoktur. Bir bireyin doğumuyla başlayan eğitim süreci yaşamı boyunca devam etmektedir. Doğumundan ilkokul eğitimine kadar çocuk ailesi, akrabaları, komşuları, okulu, öğretmenleri, arkadaşları ve okul çalışanlarıyla karşılaşmakta, çocuk karşılaştığı kişilerden de etkilenmektedir. Çünkü çocuk gelişim özellikleri bakımından çevresindeki bireyleri rol model almaktadır.

İlkokul, 2012 tarihli ve 28261 sayılı Resmi Gazete' de yayımlanan hâliyle İlköğretim ve Eğitim Kanunu İle Bazı Kanunlarda Değişiklik Yapılmasına Dair Kanununda belirtildiği üzere mecburi ilkokul çağı çocuğun 5 yaşını bitirdiği yılın Eylül ayı itibariyle başlamakta ve dört yıl sürmektedir. İlkokul dört yıl süren bir eğitim basamağıdır.

$\mathrm{Bu}$ açıdan bakıldığında zorunlu eğitim olan ilkokula gelmeden önceki sürede çocuk ailesinden eğitim almaktadır. Çocuk ailesinden yaşam kurallarını, toplumsal kuralları, birey olmanın sorumluluklarının neler olduğunu, insanlarla nasıl iletişim kurulması gerektiğini, kuralları ve bunlara neden uyulması gerektiğini, sorumluluk bilincini ailesinden öğrenmesi gerekmektedir. Ailede verilmesi ve toplumsal bir varlık olan insanın yaşamında toplumdan dışlanmadan yaşamasına yardımcı olacağı düşünülen bu davranışların ailede verilmemesi ve okulda verilmeye çalışılırken de aileden destek alınmaması gibi durumlar çeşitli sorunlara neden olmaktadır. 


\section{3. Çalışmaya Duyulan İhtiyaç}

İlkokul zorunlu eğitimin temelini oluşturan bir eğitim basamağıdır. $\mathrm{Bu}$ temel eğitimde başarıdan söz ederken öğretmen-okul-veli-öğrenci işbirliğinin sürekliliği vurgulanmaktadır. Başarının sağlanması sürecinde karşılaşılan öğrenci davranış bozuklukları, öğrenci gelişim farklılıkları, öğrencilerde görülen kural tanımama vb. gibi olumsuz durumların başarıyı olumsuz yönde etkilediği düşünülmektedir. Sınıf öğretmenleri ve rehber öğretmenlerin bu konularda tek başlarına mücadele etmeleri yeterli olamamaktadır. Bu nedenle okulda öğrencinin durumuyla rehber öğretmen ve sınıf öğretmeni ilgilenirken, okullarda ailenin eğitilmesi ve ailenin eğitimle ilgili üzerine düşen sorumluluklarının sıkı takipçisi olabilecek okul sosyal hizmet birimin kurulmasının ve birimin amacına uygun çalışmalarıyla mümkün olacağı düşünülmektedir. Öğrencinin eğitiminde velinin de önemli bir yeri olduğu için velilerin eğitilmeleri gerekmektedir. Velinin eğitilmesi ve velinin okulla irtibatının sıkı bir şekilde takip edilmesini sağlayacak olan okul sosyal hizmeti çalışmalarıyla eğitimin daha da kaliteli olmasına hizmet edeceği düşünülmektedir. Eğitimde kalitenin göstergesi olarak kabul edilmekte olan başarının sağlanmasında, öğrencilerin birbirleriyle uyum içinde yaşamasını sağlamak için faaliyetlerin yap1lması, sorunların en aza indirilmesi ve veliden kaynaklanan sorunların da mutlak surette giderilmesi için velilere destek sağlayacak faaliyetlerin yapılması ve veli eğitim hizmetlerinin verilmesi gerekmektedir. Velilerin eğitilmesi, öğrencilerde görülen davranış bozukluklarının giderilmesi, okulda şiddet gösteren öğrenciler kadar, nedensiz yere ya da küçük sebeplerden dolayı arkadaşından şiddet gören öğrencilerin de sosyal hizmet çalışmalarına ihtiyaçları olduğu düşünülmektedir. Bu çalışmayla da okul sosyal hizmeti birimlerinin geciktirilmeden kurulmalarının gerekliliğine dikkat çekilmektedir.

Okul-aile-öğrenci işbirliğinin sağlanabilmesi için sistemli çalışmaların plânlı bir şekilde yapılması gerekmekte, bunların da okul sosyal hizmeti uygulamaları ile yapılabileceği düşünülmektedir.

Çünkü okul sosyal hizmeti, okullarda okul rehberlik servisi ile bir ekip çalışması içinde öğrencilere, ailelere, öğretmenlere yönelik olarak öğrencilerin psiko-sosyal ve ekonomik ihtiyaç ve sorunlarının çözülmesi- 
ne yönelik çalışmalar yürüterek sağlıklı bir gelişim göstermesi ve eğitimden daha üst düzeyde yararlanabilmesi amaciyla uygulamalar yapan bir sosyal hizmet alanidır (Duman, 2011).

Okul sosyal hizmeti, sosyal çalışma disiplinin özel bir uygulama alanı olarak kabul edilmektedir. Öğrencinin okul başarısına ve okul performansına etki eden biopsiko-sosyal faktörler dikkate alınmaktadır. Okul sosyal hizmeti, öğrencilerin aile içindeki yaşadıkları sorunların, yaşam koşullarından kaynaklı sorunların ve içinde bulundukları gelişim dönemi sorunların çözümü, gereksinim duyulan hizmetlerden yararlanmalarını içermektedir. Öğrencilerin gerekli hizmetleri alarak sorunların çözümlenmesiyle eğitim etkinliklerini başarıyla sürdürmeleri sağlanmaktadır. Bu çalışmalar eğitim ekibi ile ekip anlayışı ile yürütülmektedir (Özbesler ve Duyan, 2009: 18).

Okullarda olması gereken okul sosyal hizmeti uygulamalarıla ailenin öğrencinin eğitim sürecine katılımını sağlamak, öğretmenle ve okulla işbirliğini arttırmak, öğrencinin performansına göre okul başarısının arttırılmasına katkıda bulunmak hedeflenmektedir. Öğrencilerin kendi gelişimlerini ve arkadaş ilişkilerini olumsuz etkileyen ve okul başarılarına engel teşkil eden biopsiko-sosyal sorunların ele alınmasında ve çözümünde görev yapabilecek disiplinlerden birisi de sosyal hizmet disiplini olarak görülmektedir. Bu sosyal hizmet disiplini okul içinde öğretmenler ve psikolojik danışmanlar ile okul dişında da öğrencinin ailesi, tedavi kurumları, sosyal hizmet ve sosyal yardım kurumları ile işbirliği ve koordinasyonunun sağlanmasında ekolojik perspektifi iyi kullanmasıyla göz ardı edilemeyecek önemli rollere sahip bir disiplin olarak görülmektedir (Özbesler ve Duyan, 2009: 24).

\section{Alan Çalışmasından Çıkan Sorunlara Yönelik Öneriler}

$\mathrm{Bu}$ çalışmada sınıf öğretmenlerinin bakış açısıyla ilkokul eğitiminde aileden kaynaklı ne tür sorunların olduğunun tespiti ve ilkokul eğitimine ailelerin nasıl katkı sağlaması gerektiğgine ilişkin önerileri araştırılmıştır. Amaç bu çalışma doğrultusunda okul sosyal hizmetinin gerekliliğinin vurgulanmasını sağlamaktır.

YIL: 5 SAYI: 9 
Bu çalışmada Yalova Üniversitesi Sosyal Bilimler Enstitüsü Sosyal Hizmet Bölümünde tez çalışması için bir okul müdürü, iki okul müdür yardımcısı, bir rehber öğretmen, bir özel eğitim sınıfına giren sınıf öğretmeni ve yirmi yedi sınıf öğretmeni olmak üzere toplam otuz iki öğretmenle yapılan kişisel görüşme (mülâkat) araştırma verilerinden yararlanılmıştır.

Öğretmenlerle yapılan kişisel görüşmede velilerin veli toplantıları d1şında öğretmenle genellikle görüşmeye gelmedikleri, veli toplantılarına katılan velilerin de yeterli sayıda olmadığı, mutlaka veli toplantılarına katılmayan veliler olduğu belirtilmiştir. Ancak velilerin okulda size maddi yardım yapılacaktır denildiğinde ise geldikleri söylenmiştir. Bu açıdan bakıldığında okulun bir eğitim kurumu olduğunun, yardım kurumu olmadığı bilincinin toplum üzerinde yeniden inşa edilmesi gerekmektedir.

Veliler arasında çocuğunun öğretmenini dahi tanımayan velilerin de olduğu, ortaokula geçtiği halde sokakta eski velilerini gördüklerinde çocuklarının ders durumunun nasıl olduğunu önceki ilkokul öğretmenine soran, çocuğunun hangi okula gittiğini dahi bilmeyen velilerin olduğu ifade edilmiştir. Bu da velilerin okulla ilgilenme durumlarını göstermektedir.

Öğretmenlerle yapılan kişisel görüşmede öğrencilerin günlük ders programına göre ders araç gereçlerini eksik getirdikleri ifade edilmiştir. Bu durum ailelerin çocuklarını ders araç gereçlerini yeterince kontrol etmedikleri sonucunu ortaya çıkarmaktadır. Ders araç gereçlerinin tam getirilmesi öğrencinin ders başarısında ve derslerini tam işleyebilmesinde önemli bir yer tutmaktadır. Çocukların evde araç gereçlerini hazırlamasında ailenin destek olması gerekmektedir. Ders programından ailenin haberi olması gerekmektedir. Araç gereçleri okula gelmeden akşamdan hazırlama alışkanlığını velinin kazandırması, bu konudaki kontrolünü de düzenli bir şekilde yapması gerekmektedir.

Öğretmenlerle yapılan kişisel görüşmede bazı öğrencilerin kahvaltı yapmadan okula geldikleri, verilen parayla kantinden alınacak ve kahvaltı ögününün yerini tutmayacak gıdalarla bu eksikliğin giderilmeye çalışıldığ belirtilmiştir. Oysa ki kahvaltı tüm bireyler için beslenmede en temel öğün olarak kabul edilmektedir. Velilerin çocuklarına kahvaltı hazırlama- 
ya ve çocuklarının kahvaltılarını yapmalarına dikkat etmeleri gerektiği ifade edilmiştir.

Öğretmenlerle yapılan kişisel görüşmede ailelerin verilen ödevleri kendilerinin yapmaya çalışmalarının sorun olarak görüldüğü söylenmiştir. Ödevlerin öğrenciye verildiği, veliye verilmediği, velinin ancak yardımcı olması gerektiği açıktır.

Ancak öğrencilere verilecek olan etkinliklerin de öğrenci tarafindan yapılabilecek nitelikte olması, öğrenci performansına uygun olması gerekmektedir.

Öğretmenlerle yapılan kişisel görüşmede ailelerin çocuklarına aşırı baskıcı ya da aşırı serbest yaklaşımlarının ve çocuğa izlettirilen filmlerin niteliğinin çocukların davranışlarında olumsuz etkilere neden olduğu belirtilmiştir. Ailelere bu konuda çok ciddi sorumluluklar düşmektedir. Ailelerin çocuklara nasıl yaklaşmaları konusunda kendilerini eğitmeleri, çocukların izleyeceği filmleri önceden kontrol etmeleri, çocuklara onların yaşlarına ve gelişimlerine uygun olmayan filmleri izlettirmemeleri gerektiği vurgulanmaktadır. Çocuk gelişimi, çocuk yaklaşımı, çocukların başarısını arttırma, nitelikli anne ve baba olma konusunda bilgi sahibi olmak için her ebeveynin kitap okuması ve kendilerini bu konuda geliştirmeleri gerekmektedir. Ailelerin sosyo-ekonomik seviyelerinin çeşitli ve devamlı kitap alma açısından yeterli olmayacağı düşünülerek bu açığın okullar arac1ğıyla kapatılabileceği düşünülmektedir.

Aile bireylerinin kitap okuma alışkanlıklarının yeterli düzeyde olmadığı bir ortamda çocuğa, özelikle de 21. yüzyıl teknolojisinin getirdiği dijital ortamlarla çok fazla karşılaşan çocuğa, sadece kitap oku demek yeterli gözükmemektedir. Aile fertlerinin kitap okuyarak çocuğa örnek olması ve birlikte kitap okumaları gerekmektedir.

Öğretmenlerle yapılan kişisel görüşmede çocuklarda temizlik alışkanlıkları konusunda sıkıntılar olduğu, öz bakım becerilerini yapamayan, el yıkama vb. gibi alışkanlıkları kazanamayan çocuklar bulunduğu, okul çantaları çok kirli olan öğrencilerin görüldüğü, çantalarda kâğıtların, beslenmelerin, kitapların birbirine karıştığı, yani kirli çantalarla çocukların okula gönderildiği belirtilmiştir. Çocuklara el yıkama, öz bakım beceri- 
lerini edinme, düzenli ve temiz olma vb. davranışların aile tarafından kazandırılması, okulda ise bunların öneminin anlatılarak pekiştirilmesi gerekir. Ailenin bu konuda üzerine düşen görevleri yapıp çocuklarına kişisel bakım eğitimini vermeleri ve temizlik alışkanlıklarına dikkat etmelerini öğretmeleri, çocukların çantalarını, kıyafetlerini kontrol etmeleri gerekmektedir.

Öğretmenlerle yapılan kişisel görüşmede ilkokul seviyesindeki bir çocuğun bilgi anlamında yarışacakları bir rekabet ortamı bulunmamasına rağmen çocukların okula karşı ilgisiz olmalarının ailelerin okula verdikleri değerle ilgili görüldüğü ifade edilmiştir.

Öğretmenlerle yapılan kişisel görüşmede ailelerin çocukların yanında öğretmenler hakkında yaptıkları konuşmaların ve bu konuşmaların çocuklar tarafindan duyulması durumunda çocukların gözünde öğretmen otoritesini yıkmaya sebebiyet verdiğini, öğretmen öğrenci ilişkisini olumsuz yönde etkilediği ifade edilmiştir. Velilerin öğretmenin tutum ve davranışlarından hoşlanmama durumları olsa da bunu çocuğun yanında belirtmemeleri gerektiği ifade edilmiştir.

Öğretmenlerle yapılan kişisel görüşmede evlerde plân, program, kural kavramlarıyla tanışmayan çocuklarda okul ortamına geldiklerinde kurallarda, plânlı ve programlı yaşama kavramlarını kavramada, uygulamada ve sorumluluklarını yerine getirmede, çevresini temiz tutmada sıkıntılar yaşandığı belirtilmişstir.

Ailelerin sene başında çocukla beraber, okul ders programına göre çocuğun ne zaman ders çalışacağına ilişkin doğru zamanın belirlenmesi için bir ders plânı hazırlamaları ve onun aile tarafından kontrol edilmesinin öğrenci başarısı açısından önem arz ettiği öğretmenlerle yapılan kişisel görüşmede belirtilmiştir. Ailelerin çocukla beraber ders çalışma plânını hazırlamaları ve çocuğun bu plâna uyup uymadığını kontrol etmeleri gerekmektedir.

Ayrıca çevreyi temiz tutma hakkında da velilerin çocuklarıyla konuşmalarının ve örnek olmalarının önemli olduğu öğretmenlerle yapılan kişisel görüşmede belirtilmiştir. 


\section{4 • YALOVA SOSYAL BILLIMLER DERGISİ}

Öğretmenlerle yapılan kişisel görüşmede ailelerin eğitim seviyelerinin düşük olması, okulda anlatılan konuların aile tarafından iyi bilinmemesi öğrencilerin derslerinin evde desteklenmesini engellemektedir. Bu nedenle de evlerde kaliteli ders tekrarları yapılamamaktadır. Bu sıkıntının giderilebilmesi için belki veli toplantılarında okulda işlenen konu başlıkları hakkında velilerin bilgilendirilme çalışmalarının ve velilere anlamadıkları konular hakkında çocuklarına yardımcı olmaları açısından bilgilendirici bilgiler verme çalışmalarının yapılabileceği düşünülmektedir.

Öğretmenlerle yapılan kişisel görüşmede velilerin çocuklarını çok iyi tanımadıklarını ve çocuklarının performanslarının neler olduğunu bilmemelerinden dolayı çocuklardan yüksek performans beklentisi içine girdikleri belirtilmektedir. Aslında her öğrencinin performansına yönelik ailelerin evde yapacağı takviyelerin neler olduğunu bilmeleri gerekmektedir. Bunun da ancak iyi bir öğretmen-veli diyalogu ile sağlanabilmesi mümkün gözükmektedir. Bu noktada velilerin öğretmenin her öğrenciye vermeyi düşündüğü farklı takviyeleri, etkinlikleri gördügünnde çocuklar arasında ayrımcılık yapıldığı düşüncesine de kapılmamaları gerekmektedir. Çünkü her öğrencinin sınıftaki potansiyeli farklı olabilmektedir. Sınıflarda genel anlamda aynı seviyede ders işlenirken evde aileler tarafinda çocukların performanslarına göre farklı takviyelerin yapılmasının onların başarılarının artmasına katkıda bulunacağı düşünülmektedir.

Öğretmenlerle yapılan kişisel görüşmede eğitimde emeksiz başarı beklemekte olan velilerin eğitime yaptıkları harcamaları gereksiz gördükleri fark edilmektedir. Velilerin her şeyi okuldan ve öğretmenden beklemeleri doğru bir davranış ve doğru bir düşünce olarak görülmemektedir. Velilerin mutlaka eğitim sürecine katılmaları gerekmektedir. Kendilerinin öğrenci konularını anlamadıklarını düşünüp kenara çekilmelerinin söz konusu dahi olmaması, ailelerin çocukların defterlerini, kitaplarını kontrol etmeleri, yazılarına bakmaları, okumalarını takip etmeleri, günlük ders tekrarı yapma alışkanlıklarını kontrol etmeleri, günlük okulda öğrendiklerini sormaları onların, öğrencinin başarısını arttırmak için yapabilecekleri arasında belirtilmiştir.

YIL: 5 SAYI: 9 
Öğretmenlerle yapılan kişisel görüşmede sınıf içerisinde görülen bir tane olumsuz davranışı olan öğrencinin tüm sınıfı etkilediği, çünkü çocukların model alarak öğrenme çağında oldukları, velilerin her zaman ve hassasiyet içerisinde bu konuda daha duyarlı olmaları gerektikleri belirtilmektedir. Velilerin çocuk büyütmekte değil çocuk yetiştirme konusunda eksiklikler yaşadığ projelerle mutlaka giderilmesinin gerektiği vurgulanmıştır. Velilere çocuk yetiştirme konusunda eğitimin verilmesi ve velilerin de bu konuda daha duyarlı olmaları gerekmektedir.

Velilerin bu konuda eğitimlerinin sağlanması sadece davranış problemi olan öğrenciyi değil, davranış problemi olan öğrencilerden diğer öğrencilerin de etkilendiği düşünüldüğünde davranış problemlerinin ciddi anlamda çözülmesi için okul sosyal hizmet birimi çalışanlarına ihtiyaç duyulmaktadır. Çünkü problemli görülen davranışların kaynağının tespit edilmesi için öğretmen, veli, öğrenci diyalogu sağlanarak etkili çalışmaların yapılması gerekmektedir. Psikolog, sosyolog, sosyal çalışmacı gibi çalışanların varlığı ve işbirliğinde, okul sosyal hizmet birimlerinde bu tür problemlerin veli eğitimiyle, okul, öğretmen, öğrenci işbirliğiyle çözülebileceği düşünülmektedir. Öğrenci davranışlarında görülmekte olan davranış bozuklukları sadece öğretmen tarafından okulda çözülebilecek bir konu olmamaktadır.

Öğretmenlerle yapılan kişisel görüşmede çocuğun okul başarısını arttırmak için aile desteğinin mutlaka olması gerektiği belirtilmiştir. Ayrıca çocukların gelişimi açısından ailelerin mutlaka çocuk yetiştirme konusunda eğitilmeleri gerektiği vurgulanmıştır. Bu da aile eğitiminin gerekli olduğunu açıklamaktadır.

\section{Sonuç}

Okul sosyal hizmeti birim çalışmalarıyla okul kurallarına uyumda sorun yaşayan, tüm uyarılara rağmen sürekli arkadaşlarına şiddet gösteren, ailevi problemler yaşayan, bu sorunlara bağlı olarak ders başarısı düşen öğrenciler ve aileleri için mutlaka okul sosyal hizmeti faaliyetlerinin 
olması gerekmektedir. Ailede anne ve babaların çocuklarına tutarlı davranmaları gerektiğinin öneminin vurgulanması, plânlı ve düzenli çalışma ortamı hazırlamada ailenin duyarlı olmasının açıklanması, çocuklarının gelişim özellikleri hakkında bilgiler verilmesi doğrultusunda aile eğitimlerinin verilmesi gerekmektedir.

Sorunların süreklilik arz etmeden büyümesinin engellenmesi için ailelerin eğitime katkılarının mutlaka sağlanması, bu katkının takip edilmesi ve ailelerin eğitilmesi gerekmektedir. Bu nedenle öğrencinin başarılı ve çevresine faydalı olacak şekilde eğitimine devam etmesinin sağlanması, çevresindeki olumsuz durumlardan ve kişilerden nasıl korunacağının anlatılıp destek sağlanabilmesi için sosyal çalışmacı, psikolog ve sosyologun beraber çalıştıkları bir okul sosyal hizmeti biriminin okullarda kurulması gerekmektedir. Ancak okul sosyal hizmeti biriminin çalışmalarını sınıf öğretmeni ve rehber öğretmenle birlikte koordineli yürütmesi gerekmektedir.

Bir sınıf öğretmeninin öğrencilerin başarısı için hem onlara müfredatta yer alan kazanımları kaliteli bir şekilde vermeye çalışması hem eğitim öğretim faaliyetlerini yapamaya çalışması hem de bunların yanı sıra istenmeyen durumlar olarak karşılaşılan öğrenci davranış problemlerini çözmede tek başına mücadele etmesi mümkün olamadığı kabul edilmelidir. Okullarda bulunan rehberlik servisinde görevli rehber öğretmenlerle de bazı sorunlar çözülmeye çalışılsa da hedeflere tam anlamıyla ulaşmanın mümkün olamadığı, çünkü veliden kaynaklanan sorunların çözülmesi için bazı velilerin istenilen duyarlılı̆̆ göstermediği sonucuna ulaşılmıştır.

Bu anlamda okullarda mutlaka sınıf öğretmenlerinin ve rehber öğretmenlerinin bilgilerinden yararlanarak öğrenci ve aile ile ilgilenecek sosyal hizmet uygulama çalışmalarının yapılması, bunun için de okul sosyal hizmet birimlerinin kurulması gerekmektedir. Ailelerin yaşadığı bazı psikolojik sorunların tanımlanması, yaşanılan çevrenin aile üzerine etkisinin araştırılması için sosyal hizmet biriminde sosyal çalışmacıyla birlikte çalışacak bir psikolog, bir sosyolog olması ve bunların da mutlaka sınıf öğretmeni, okul rehber öğretmeni ve okul idaresiyle işbirliği içerisinde çalışması gerekmektedir.

YIL: 5 SAYI: 9 
Okul sosyal hizmeti çalışmaları için ailenin yakından takip edilmesi gerekmektedir. Bunun yanı sıra sınıf öğretmeni ve rehber öğretmenin de öğrenciyi okulda takip etmesi gerekmektedir.

Okul sosyal hizmet biriminde çalışacak kişilerin çocuğun içinde yaşadığı aile ortamının nasıl olduğunu görmek için mesai saatleri içinde aile ziyaretleri yapıp anne, baba ve eğer varsa diğer aile büyükleriyle görüşüp çocuğun gelişimi hakkında çıkarımlarda bulunabileceği, çocukla yapılacak görüşmeler sonucunda da bu bilgilerin birleştirilip çocuğun nasıl bir yaşantısı olduğu, bu yaşantıda görülen aksaklıkların giderilebilmesi için yapılabilecekler hakkında çalışmaların plânlanması ve uygulanması gerekmektedir.

Bir öğrencinin okul başarını arttırmada, davranış problemlerinin çözülmesinde aile-öğretmen-öğrenci-okul işbirliğinin olması gerekmektedir. Çünkü bu işbirliğinde yapılması gerekenlerin aile, öğretmen, öğrenci ve okul tarafından paylaşılması gerekmektedir. Okul sosyal hizmetleriyle ailenin eğitim öğretim sürecine katılmalarını sağlamak ve problemleri var olan ailelerin ve öğrencilerin problemlerini çözmek için onlara yol göstermek, yardımci olmak, ailelerin okul sosyal hizmet birimindeki psikologlar ile çocuk gelişimi hakkında bilgi sahibi olmalarını sağlanabileceği düşünülmektedir.

Okullardaki başarı düzeylerinin gerçekten ailelerin bilinçli olarak eğitim öğretime katılmalarıla, okula, eğitime ve öğretmene önem ve değer vermeleriyle, eğitimi sadece okuldan ve öğretmenden beklememeleriyle sağlanacağı düşünülmektedir.

Okul ortamlarında eğitim öğretimin kaliteli olabilmesi için ailelerin eğitilmesi, öğrencilerin davranış bozukluklarının çözülebilmesi, öğretmen-veli-okul-öğrenci işbirliğinin etkili bir şekilde yapılabilmesi, ailelerdeki kitap okuma alışkanlığının takip edilmesi, veli toplantılarına katılımın takip edilebilmesi için okul sosyal hizmeti çalışmalarının yapılması gerekmektedir. 
$198 \cdot$ YALOVA SOSYAL BILIMLER DERGISI

\section{KAYNAKÇA}

Arın, T. (1997), “Sosyal Hakların Emek Gücünün Meta Niteliği Üzerindeki Etkileri” Kamu Girişimciliği, TMMOB, Ankara.

Bozkır Serdar, A. (2011),"Sosyal Politika Kavramı, Tarihsel Gelişimi ve Türkiye'de Sosyal Politika", Editörler: Tokol, A. ve Y. Alper, Sosyal Politika, 1. Bask1, Bursa: Dora Yayınları, ss. 1-33.

C1lga, İ. (2002), “Aydınlanma Felsefesi ve Sosyal Hizmet”, 5. Ulusal Sosyal Hizmetler Konferans1, Ankara 21-23 Mayıs 1999, Değişen Türkiye'de İnsan Hakları ve sosyal Hizmetler, Ankara: Sosyal Hizmet Uzmanları Derneği Yay. No: 6.

Çengelci E. (1996), Cumhuriyet Türkiye'sinde Sosyal Hizmetlerin Örgütlenmesi, Ankara: Sevinç Matbaası.

Dupper, D. R., (2013), Okul Sosyal Hizmeti Etkin Uygulamalar İçin Beceri ve Müdahaleler, Çev., Yasemin Özkan, Elif Gökçearslan Çiftçi, Kapital Yayınları, İstanbul.

Duman, N., (2011), "Okul Sosyal Hizmeti Alanında Mesleki Değerlerin Uygulamaya Aktarımı", Değerler Eğitimi Sempozyumu, Pegem. Net Eğitim Bilimleri İndeksi, http://www.pegem.net/Akademi/ sempozyumbildiri_detay.aspx?id=126675, 16/07/2014.

Gerek, N. ve Oral, A.İ., (2004), Sosyal Güvenlik Hukuku, Eskişehir: Anadolu Üniversitesi Yayınları, No: 1574.

Göze, A., (1995), Siyasal Düşünceler ve Yönetimler, İstanbul: Beta Yayınları.

Kahvecioğlu, A. (2014), "Her Okula Bir Sosyal Hizmet Birimi Kuracak”, http:// www.memurlar.net/haber/458331/, 12/05/2014.

Kesgin, B. (2013), Kamu Sosyal Politikalarında Sosyal Yardım, 1. Baskı, Aç1lım Kitap, İstanbul.

Koray, M., (2005), Sosyal Politika, 2. Baskı. İstanbul: İmge. Özbesler, C. ve V. Duyan; (2009), "Okul Ortamlarında Sosyal Hizmet", Eğitim ve Bilim, Cilt: 34, Say1, 154, Ekim, s: 17-24, http://egitimvebilim.ted.org.tr/index. $\mathrm{php} / \mathrm{EB} /$ article/view/545/33, 01.06.2014.

Koşar, N. G., (2000), Sosyal Hizmetlerde Sosyal Yardım Alanı, Ankara: Şafak Matbaacilik.

Seyyar, A. ve Y. Genç; (2010), Sosyal Hizmet Terimleri Sözlüğü, 1. Bask1, Sakarya Yayıncılık, Sakarya.

Tomanbay, İ., (1999), Sosyal Çalışma Sözlüğü, Selvi Yayınevi, Ankara.

Tomanbay, İ., (2001). "Türkiye'nin Sosyal Politika İçinde Sosyal Hizmetlerin Durumu", HÜ. Sosyal Hizmet Yüksekokulu. Sosyal Hizmet Sempozyumu, 2001.

Yavuzer, H., (2001), Okul Çă̆ı Çocuğu, 7. Basım, Remzi Kitabevi, İstanbul. http://www.resmigazete.gov.tr/eskiler/2012/04/20120411-8.htm, 28/05/2014. 